\title{
Nutritional evaluation of processed cassava root meal using albino rats
}

\begin{abstract}
Twenty- one days experiment was carried out using thirty-two Wistar strains of white albino rats to determine the energy level of cassava root meal. Four diets were formulated. Diet 1 contain corn-starch based diet (basal diet), Diet 2-4 contain (Sun dried, Fermented and Rumen ensiled-digesta cassava root meal) as a sole energy source. The experimental diets were offered to the rats ad libitum while clean water was supplied on a daily basis. Thirty -two albino rats were used in the study in which eight rats were allotted to different dietary treatment. The result showed that the diet has significant $(\mathrm{P}<0.05)$ effect on growth performance with the value of 95.0076.5 (g/birds) live weight. Rats fed corn based meal has significantly better growth performance compared with rats fed diet 2-3. The hematological indices and serum metabolites parameter rats fed fermented cassava root meal has higher $\mathrm{Hb}$ numerical value $15.00 \pm 1.29(\mathrm{~g} / \mathrm{dl})$ while rat fed RDECRM had the least value of $12.5 \pm 2.6(\mathrm{~g} /$ dl). Rat fed basal diets had least glucose value while rat fed fermented cassava root meal had the highest value of $81 \pm 1.69-65 \pm 1.70(\mathrm{mg} / \mathrm{dl})$. Total protein of rat fed sun dried cassava root meal were higher compared to rat fed fermented cassava root meal $8.6 \pm 0.42-7.4 \pm 0.28(\mathrm{mg} / \mathrm{dl})$. The result indicated that cassava root meal could replaced maize at $10 \%$ of replacement without any deleterious effect on the performance characteristics and blood parameters of albino rats.
\end{abstract}

Volume 7 Issue 5 - 2017

\author{
Akapo OA,' Olayemi WA, ${ }^{3}$ AO Oso,' \\ Olorunsola RA, ${ }^{2}$ Bamgbose $A M^{2}$ \\ 'Department of Animal Nutrition, College of Animal Science and \\ Livestock Production, University of Agriculture, Nigeria \\ ${ }^{2}$ Biological Science Department, Ondo State University of \\ Science and Technology, Nigeria \\ ${ }^{3}$ Yaba College of Technology, Nigeria
}

Correspondence: Akapo OA, Department of Animal Nutrition, College of Animal Science and Livestock Production, University of Agriculture, PMB 2240,Abeokuta, Nigeria, Email aolajetemi@gmail.com

Received: April 06, 2017| Published: October 04, 2017

\section{Introduction}

Cassava (Manihot esculenta Crantz), a shrubby tree of the Euphorbiaceous family, is an extensively cultivated plant in many tropical countries. Annual production estimate in Nigeria was 34million tonnes in 2009 FAO. ${ }^{1}$ Cassava root is a major source of dietary carbohydrate for human and livestock. It is widely accepted that plants grown in various location produced different quality and quantity of substances. Cassava products had been in use for a long time as an energy source in place of cereal grains for livestock Eruvbetine. ${ }^{2}$ There is thus the likelihood of continued use of cassava in animal feeding in the 21 st century and beyond. Known cases of acute $\mathrm{HCN}$ poisoning from the consumption of cassava are rare, probably because preparation process of cassava for consumption can destroy the linamarase and remove much of the free HCN. Due to the toxic cyanogenic glucoside several processing methods have been used to process fresh cassava root in order to reduce the cyanide content. These methods include grating, sun drying, oven drying and boiling Osei and Duodu. ${ }^{3}$ Previous studies reported that ensiling and fermentation are the most effective ways to eliminate cyanogenic substances whereas oven drying method is the least effective way Tewe. ${ }^{4}$ The residual level of cyanogenic glucoside in processed cassava would therefore depend upon the processing method used. Thus, this study is therefore designed to determine the energy level of cassava root meal on the performance, hematology and serum metabolite of albino rats.

\section{Material and methods}

\section{Experimental site}

The feeding trial was carried out at the Directorate of University farms (DUFARMS) of the Federal University of Agriculture, Abeokuta (FUNAAB), Ogun State.

\section{Experimental rat and design}

Twenty- one days experiment was carried out using thirty-two (32) Wistar strains of white albino rats with average weight of $40 \mathrm{~g}$, sourced from Veterinary Pathology University of Ibadan. The rats were housed individually in stainless steel metabolic cages and allotted on weight equalization basis into four dietary treatments consisting of 8 rats per treatments. The treatments consist of a standard corn-starch based diet (basal diet) and 3 other experimental diets where each of the processed cassava roots (SDCRM, FCRM and RECRM) were used as a sole energy source. The experimental diets were offered to the rats ad libitum while clean water was supplied on a daily basis.

\section{Preparation of test ingredients}

Freshly harvested matured cassava tubers (TMS-30573) were purchased from local farmers within Abeokuta metropolis, Ogun State. Harvesting and processing was done during dry season (September December) to enhance proper drying. The whole cassava tubers were washed in clean water to remove dirt and subjected to the following processing methods:

\section{Sun-drying}

The freshly unpeeled cassava tuber were chipped manually into smaller sizes using a sharp knife, washed in clean water and spread thinly on a clean polythene sheets for 3-4days until it was dried to a constant weight $(10-11 \% \mathrm{MC})$. This was achieved by turning at intervals to enhanced dried cassava chips, the cassava chips were milled to yield sun-dried cassava root meal (SDCRM)

\section{Fermentation}

Freshly unpeeled cassava tuber were manually chipped into smaller sizes using a sharp knife, washed in clean water and soaked in water (at a ratio of 1:2; $\mathrm{kg}$ cassava tuber/Lt water) in an air tight, 
plastic container drum for 3 days. At the end of 3 days fermentation period, the fermenting liquid was drained, fermented tuber masses were carefully collected in jute sacs. This was screw-pressed overnight under a manually operated cassava screw-press; clogs of the pressed fermented tubers were sun-dried by manually crushing the hard crumbs and spreading on polyethylene sheets for 3-4days. These were turned at intervals to enhance proper drying. The dried tuber was milled $(2.5 \mathrm{~mm}$ sieve) to yield the fermented cassava root meal (FCRM).

\section{Ensiling process}

Fresh rumen digesta (from cattle) was collected from a near-by abattoir at the point of slaughter in a plastic container. The fresh digesta was mixed with fresh cassava root manually (at a ratio of $2 \mathrm{~kg}$ cassava root: $1 \mathrm{~kg}$ rumen digesta) and carefully set in a black plastic drum for ensiling period. The mixtures were covered up using a polyethylene sheet, under an air tight condition, and left for 21days ensiling period. At the expiration of 21days, the ensiled mixture of cassava tuber and rumen digesta were removed from the plastic drum and sun-dried for 3-4days until constant weight is obtained. This were milled and bagged to obtain the rumen- digesta ensiled cassava root meal (RDECRM).

\section{Measurement of parameters}

Growth performance: Daily intakes of feed were recorded by subtracting the amount of left- over feed from feed offered after 24 hours. Weekly weight gain was calculated by subtracting the initial weight from the final weight. The feed conversion ratio was calculated by computing the ratio of amount of feed intake to weight gain while the protein efficiency ratio was computed by finding the ratio of weight gain to protein consumed.

Blood parameters: At the end of 21days, blood sample were collected from 3 rats per treatment using hypodermic needle and syringe. Blood was drained into different carefully label bottles for hematological and serum biochemical investigation, the blood samples for haematological parameters was collected into bottles containing ethylene diamine tetra acetate (EDTA) an anticoagulant, while blood samples for bio chemical indices was collected into another sample bottles containing no anti-coagulant. Packed cell volume (PCV) was determined using win robes microhaematological method Baker et al. ${ }^{5}$ Haemoglobin $(\mathrm{Hb})$ and red blood cell $(\mathrm{RBC})$ concentration was determined by a cyanmethaemoglobin method Benjamin. ${ }^{6}$ Total leukocyte counts was determined using Neubauer haemocytometer after appropriate dilution, and differential leukocyte counts was performed using the oil - immersion objective examination of blood films stained with the modified Romanov sky's Giemsa stain.

\section{Serum biochemical determination}

Burette method of total serum protein determination was employed in this study as described by Kohn et al. ${ }^{7}$ Serum albumin was determined using Bromocresol Green (BCG) method as described by Peter et al. ${ }^{8}$ The serum globulin concentration was obtained by subtracting albumin concentration from the total serum protein. The albumin/globulin ratio was obtained by dividing the calculated albumin value by the calculated globulin value. Aspartate amino transferase (AST) and alanine amino transferase (ALT) activities were determined using spectrophotometric methods as described by Hoder et al. ${ }^{9}$ Serum creatinine (SC) was determined using the principle of Jaffe reaction as described by Bonsnes et al. ${ }^{10}$ while the serum uric acid (SUA) was determined using the Kit (Quinica Clinica Spain) as described by Wootton. ${ }^{11}$

\section{Statistical analysis}

Data generated were arranged in a Complete Randomized design and analyzed using one - way analysis of variance SAS ${ }^{12}$ statistical package. Duncan multiple range text was used to separate significant mean values Duncan. ${ }^{13}$

\section{Result and discussion}

Table 1 showed the composition of experimental diets fed to albino rats. The table comprised of the basal diets (Treatment 1), SDCRM, (Treatment 2), FCRM, (Treatment 3) and RDECRM (Treatment 4). Table 2 showed the effect of cassava processing methods on performance characteristics of rat fed the experimental diets. The cassava meal had significant $(\mathrm{P}<0.05)$ effect on final live weight, weight gain average feed intake on weekly basis. Rat fed basal diets had the $(\mathrm{P}<0.05)$ highest live weight gain and weight gain while birds fed rumen digesta -ensiled cassava had the least. Rat fed RDECRM had the $(\mathrm{P}<0.05)$ highest average feed intake while rat fed sun dried cassava recorded the $(\mathrm{P}>0.05)$ least average feed intake. Rats fed with basal diet gained more weight than those fed with cassava meal. This may be due to the high fibre content and low sulphur amino acids (lysine and tryptophan) in cassava root meal. This corroborates the reports of Umar et al. ${ }^{14}$ Who reported that animal fed with proteins deficient diets tends to lost weight and growth. Table 3 summarized the haematological indices of rat fed the experimental diets.

Table I Gross composition (\%) of experimental diet for rat

\begin{tabular}{lllll}
\hline Ingredient & Basal & DCRM & FCRM & RECRM \\
\hline Corn Starch & 54.64 & 0 & 0 & 0 \\
Cassava & 0 & 54.64 & 54.64 & 54.64 \\
Casein & 11.26 & 11.26 & 11.26 & 11.26 \\
Glucose Monohydrate & 5 & 5 & 5 & 5 \\
Sucrose & 10 & 10 & 10 & 10 \\
Non-nutritive Cellulose & 5 & 5 & 5 & 5 \\
Bone Meal & 2 & 2 & 2 & 2 \\
Oyster Shell & $\mathrm{I}$ & $\mathrm{I}$ & $\mathrm{I}$ & $\mathrm{I}$ \\
Vit-min(premix) & $\mathrm{I}$ & $\mathrm{I}$ & $\mathrm{I}$ & $\mathrm{I}$ \\
Salt & 0.2 & 0.2 & 0.2 & 0.2 \\
Total & 100 & 100 & 100 & 100 \\
\hline
\end{tabular}

There were significant $(\mathrm{P}<0.05)$ effect on $\mathrm{PCV}, \mathrm{HB}, \mathrm{RBC}, \mathrm{WBC}$, $\mathrm{MCHC}$, heterophil and Lymphocyte. The higher value of PCV recorded may be as result of the processing methods employed in this study. The WBC values of rat fed RDECRM diet groups shows significantly $(\mathrm{P}<0.05)$ different when compared to other diets. This shows that the rats developed higher immunity against any deleterious effect of $\mathrm{HCN}$ in the cassava root meal. The $\mathrm{Hb}$ level of rat on diets were still within range reported in the literature by Bucklan et al. ${ }^{15}$ The higher $\mathrm{Hb}$ level recorded by rat fed FCRM may be due to the higher content of iron in the processed cassava root meal. The PCV value of rat fed FCRM were significantly $(\mathrm{P}>0.05)$ higher than those fed other diets. The values still fall within the range reported by Coles. ${ }^{16}$ This is in accordance with the report of Swenson. ${ }^{17}$ The high MCHC which provides an index of the average haemoglobin value indicates 
sufficient haemoglobin synthesis Endex. ${ }^{18} \mathrm{MCH}$ gives an estimate of the average hemoglobin content of each red cell. The MCV value reflects the average volume of each red cell Cheesbrough ${ }^{19}$ but MCV showed no significant $(\mathrm{P}<0.05)$ value in this study. Table 4 showed the effect of cassava processing methods on serum metabolites of rat fed the experimental diets. The cassava meal had significant $(\mathrm{P}<0.05)$ effect on glucose, total protein, albumin and ALT, rat fed basal diet had the highest glucose value while rat fed FCRM recorded the $(\mathrm{P}<0.05)$ the least glucose value. Rat fed SDCRM and FCRM had the highest total protein compared to rat fed RDECRM. Rat fed basal diets had $(\mathrm{P}<0.05)$ highest AST value compared to others. The increased in serum protein revealed that there is no indication of liver dysfunction on the rat fed the experimental diets Umar et al. ${ }^{14}$

Table 2 growth performance of rat fed maize based diets and processed cassava root meal

\begin{tabular}{lllll}
\hline Parameters & Basal diets & \multicolumn{2}{l}{ Sun-dried cassava Fermented cassava } & Rumen digesta -ensiled cassava \\
\hline Initial weight $(\mathrm{g} /$ Bird $)$ & $40.00 \pm 0.01$ & $40.00 \pm 0.01$ & $40.00 \pm 0.01$ & $40.00 \pm 0.01$ \\
Final live weight $(\mathrm{g} / \mathrm{bird})$ & $135.00 \pm 3.2^{\mathrm{a}}$ & $126.00 \pm 2.1^{\mathrm{b}}$ & $118.00 \pm 2.2^{\mathrm{c}}$ & $116.50 \pm 1.8^{\mathrm{d}}$ \\
Weight gain $(\mathrm{g} / \mathrm{bird})$ & $95.00 \pm 1.1^{\mathrm{a}}$ & $86.00 \pm 0.09^{\mathrm{b}}$ & $78.00 \pm 1.20^{\mathrm{c}}$ & $76.5 \pm 1.1^{\mathrm{d}}$ \\
AVFI $(\mathrm{g} / \mathrm{bird})$ & $50.2 \pm 0.10^{\mathrm{b}}$ & $40.04 \pm 1.3^{\mathrm{c}}$ & $44.00 \pm 1.4^{\mathrm{d}}$ & $64.00 \pm 0.28^{\mathrm{a}}$ \\
$I^{\text {st }}$ week & $62.33 \pm 1.6^{\mathrm{b}}$ & $51.20 \pm 1.0^{\mathrm{c}}$ & $54.45 \pm 0.20^{\mathrm{d}}$ & $70.06 \pm 0.14^{\mathrm{a}}$ \\
$2^{\text {nd }}$ week & $77.01 \pm 0.5 \mathrm{I}^{\mathrm{b}}$ & $54.45 \pm 1.1^{\mathrm{c}}$ & $46 \pm 2.0^{\mathrm{d}}$ & $84 \pm 1.2^{\mathrm{a}}$ \\
$3^{\text {rd }}$ week & $89.5 \mathrm{I} \pm 1.8^{\mathrm{b}}$ & $70.06 \pm 1.5^{\mathrm{c}}$ & $56.09 \pm 3.0^{\mathrm{d}}$ & $98.70 \pm 2.4^{\mathrm{a}}$ \\
\hline
\end{tabular}

Table 3 Haematological indices of albino rat fed maize based diets and processed cassava root meal

\begin{tabular}{|c|c|c|c|c|}
\hline Parameters & Basal diets & $\begin{array}{l}\text { Sun-dried } \\
\text { cassava }\end{array}$ & Fermented cassava & Rumen digesta -ensiled cassava \\
\hline PCV (\%) & $43.00 \pm 4.9^{\mathrm{a}}$ & $40.10 \pm 4.0^{\mathrm{a}}$ & $49.00 \pm 3.9^{\mathrm{a}}$ & $38.2 \pm 2.7^{b}$ \\
\hline $\mathrm{Hb}(\%)$ & $13.6 \pm 0.9^{b}$ & $14.3 \pm 2.9^{\mathrm{a}}$ & $15.00 \pm 1.29^{\mathrm{a}}$ & $12.5 \pm 2.6^{b}$ \\
\hline $\mathrm{RBC}(\times 103)$ & $9.10 \pm 0.8^{a}$ & $8.60 \pm 0.8^{a}$ & $6.60 \pm 0.5^{b}$ & $7.90 \pm 0.6^{b}$ \\
\hline $\mathrm{WBC}(\times 1012)$ & $6.0 \pm 0.2^{c}$ & $5.4 \pm 0.0 \mathrm{I}^{\mathrm{d}}$ & $7.5 \pm 0.3^{b}$ & $9.6 \pm 0.8^{a}$ \\
\hline $\mathrm{MCV}(\mathrm{fl})$ & $45.05 \pm 3.9$ & $44.7 I \pm 4.5$ & $43.59 \pm 2.7$ & $43.59 \pm 3.4$ \\
\hline $\mathrm{MCH}(\mathrm{pg})$ & $14.95 \pm 0.05$ & $|4.7| \pm 0.66$ & $14.07 \pm 1.2$ & $|3.8| \pm 0.0 \mid$ \\
\hline $\mathrm{MCHC}(\mathrm{g} / \mathrm{dl})$ & $34.05 \pm 0.67^{\mathrm{a}}$ & $33.4 I \pm 0.76^{b}$ & $22.17 \pm 0.48^{c}$ & $30.86 \pm 0.35^{b}$ \\
\hline Heterophil (\%) & $43 \pm 1.2^{c}$ & $48 \pm 1.4^{b}$ & $45 \pm 1.5^{c}$ & $55 \pm 1.9^{a}$ \\
\hline Lympocyte (\%) & $50 \pm 0.42^{\mathrm{a}}$ & $48 \pm 0.22^{\mathrm{b}}$ & $46 \pm 0.24^{b}$ & $39 \pm 0.3^{c}$ \\
\hline Eosinophil (\%) & $3 \pm 0.01$ & $3 \pm 0.01$ & $4 \pm 0.02$ & $3 \pm 0.01$ \\
\hline Monophil (\%) & $\mathrm{I} \pm 0.0 \mathrm{I}$ & $2 \pm 0.0 \mathrm{I}$ & $2 \pm 0.01$ & $\mathrm{I} \pm 0.0 \mathrm{I}$ \\
\hline
\end{tabular}

Table 4 Serum chemistry of albino rat fed maize based diets and differently processed cassava root meal

\begin{tabular}{lllll}
\hline Parameters & Basal diets & Sun-dried cassava & Fermented cassava & $\begin{array}{l}\text { Rumen digesta -ensiled } \\
\text { cassava }\end{array}$ \\
\hline Glucose $(\mathrm{mg} / \mathrm{dl})$ & $81 \pm 1.69 \mathrm{a}$ & $79 \pm 1.66 \mathrm{~b}$ & $65 \pm 1.70 \mathrm{c}$ & $79 \pm 2.67 \mathrm{~b}$ \\
Creatinine $(\mathrm{mg} / \mathrm{dl})$ & $0.53 \pm 1.04$ & $0.67 \pm 1.24$ & $0.45 \pm 1.34$ & $0.44 \pm 1.14$ \\
Uric acid $(\mathrm{mg} / \mathrm{dl})$ & $2.2 \pm 0.22$ & $2.2 \pm 0.20$ & $2.1 \pm 0.1 \mathrm{l}$ & $2.4 \pm 0.13$ \\
Total protein $(\mathrm{mg} / \mathrm{dl})$ & $8.3 \pm 0.6 \mathrm{lb}$ & $8.6 \pm 0.42 \mathrm{a}$ & $8.4 \pm 0.3 \mathrm{la}$ & $7.4 \pm 0.24 \mathrm{c}$ \\
Albumin $(\mathrm{mg} / \mathrm{dl})$ & $5.6 \pm 0.34 \mathrm{~b}$ & $4.5 \pm 2.2 \mathrm{c}$ & $5.9 \pm 3.5 \mathrm{~b}$ & $6.0 \pm 4.2 \mathrm{a}$ \\
AST (ui/L) & $38 \pm 4.6 \mathrm{la}$ & $24 \pm 3.4 \mathrm{lc}$ & $31 \pm 3.5 \mathrm{lb}$ & $22 \pm 2.33 \mathrm{c}$ \\
ALT (ui/L) & $45 \pm 0.42$ & $40 \pm 0.33$ & $38 \pm 0.34$ & $37 \pm 0.30$ \\
Cholesterol $(\mathrm{g} / \mathrm{dl})$ & $102 \pm 5.6$ & $99 \pm 3.5$ & $87 \pm 4.7$ & $83 \pm 3.7$ \\
\hline
\end{tabular}

SDCRM, Sun dried cassava root meal; FCRM, fermented cassava root meal; RDECRM, rumen digesta ensiled cassava root meal 


\section{Acknowledgements}

None.

\section{Conflict of interest}

The author declares no conflict of interest

\section{References}

1. FAO. Food and Agriculture Organization. Food outlook; 2009. p. 1-30.

2. Eruvbetine D, Tajudeen ID, Adeosun AT, et al. Cassava (Manihot esculenta) leaf and tuber concentrate in diets for broiler chickens. Bio Resource Technology. 2003;86(3):277-281.

3. Osei SA, Duodu S. The use of sun dried cassava peels meal in broiler diets. J Anim Prod Res. 1988;69(3):2739-276.

4. Tewe OO, Kasali OB. Effect of cassava peel processing on the performance, nutrient utilization and physiopathology of the African giant rat (Cricetomy gambianus, water house). Trop Agri(Trinidad). 1986;63:125-128

5. Baker FI \& Silverton RE. Introduction to Medical Laboratory Technology. 5th Educational Publish. Butterworth SC United Kingdom; 1988. p. $481-494$

6. Benjamin MM. Utline of Veterinary Clinical Pathology. 2nd ed. USA Iowa State University Press Iowa; 1978. p. 35-105.

7. Kohn RA, Allen MS. Enrichment of Proteolitic activity relative to Nitrogen in preparation from the rumen for in vitro studies. Animal Feed Science and Technology. 1995;52(1-2):1-14

8. Peters E, Neyt A, Beckers F, et al. Influence of supplement magnesium tryptophan vitamin $\mathrm{C}$, vitamin $\mathrm{E}$, and herbs on stress response and park quality. J Anim Sci. 9182;84(7):1568-1580.
9. Hoder M, R Rej. Alanine transaminase. In Methods of Enzymatic Analysis. 3rd ed. HU Bergmeyer, J Bergmeyerand M Grassl, Verlag Chemie, Weinheim Germany; 1983. p. 380-401.

10. Bonsnes R Tausslay HH. Introduction colorimetric determination of creatinine by Jaffe reaction. Biochemistry. 9145;158:581-591591.

11. Wootton T D. Micro analysis in medical biochemistry. 4th ed. USA: Churchill Ltd; 1964. p. 66-69.

12. SAS Institute. SAS/STAT guide for personal computers. version 6th ed. Cary, NC, USA: SAS Institute; 1990

13. Duncan DB. Multiple range and Multiple test F. Test Biometric. 1955;11(1):1-142.

14. Umar IA, Sa'id Y, Lawal M. Comparative study of nutrient composition of millet and maize based complementary weaning food. Nig J Basic \& Appl Sc. 2008;16(2):282-287.

15. Buckland DM, Hall L, Morolem A, et al. A Guide to Animal Laboratory Technology. 1st ed. William Heinman Medical Book Ltd London 200. Dukes Physiology of Domestic Animals. 10th ed. USA: Cornel University press; 1981 .

16. Coles EH. Veterinary clinical pathology. 4th ed. USA: WB sanders company Philadelphia; 9186.

17. Swenson MJ. Physiological Properties cellular and chemical constituents of blood Dukes Physiology of Domestic Animals. 10th ed. USA: Cornel University press; 1990.

18. Endex. The complete drug formulary for Nigeria's Health. Professionals. Lagos, Nigeria: 2007. p. 619-620.

19. Cheesbrough M. Medical Laboratory Manual for Tropical Countries. USA: Butterworth and Co. Ltd; 2003. p. 100-195. 